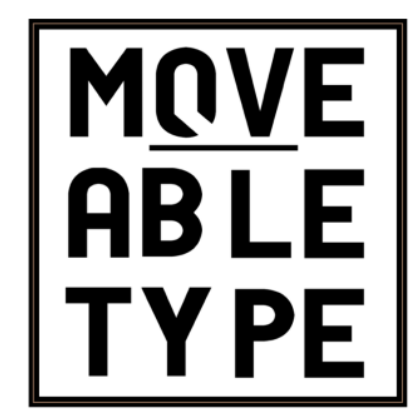

[Review] Forgetfulness: Making the Modern Culture of Amnesia

Author[s]: Kay J. Walter

Source: Moveable Type, Vol.11, 'Decadence' (2019)

DOI: $10.14324 / 111.1755-4527.103$

Moveable Type is a Graduate, Peer-Reviewed Journal based in the Department of English at UCL.

(C) 2019 Kay J. Walter. This is an Open Access article distributed under the terms of the Creative Commons Attribution License (CC-BY) 4.0https://creativecommons.org/licenses/by/4.0/, which permits unrestricted use, distribution, and reproduction in any medium, provided the original author and source are credited. 


\title{
Reclaiming Memory
}

Dr. Kay J. Walter

\begin{abstract}
Forgetfulness: Making the Modern Culture of Amnesia.
Francis O'Gorman. 2017. X + 185p. £,14. Bloomsbury Academic.
\end{abstract}

ISBN 987-1-5013-2469-7

Francis O’Gorman's new book offers a piercing insight into the modern era's fascination with newness and the resulting cultural implications. It expounds the recent thoughts of a critically acclaimed author who views contemporary life as decadent because of its abnegation of historical truths and who is wise enough both to predict the outcomes and also to identify cultural evidences of resistance to this trend.

From a professor's perspective, I know that I have read a book worth my time and effort when I find it transforming how I see my daily life. Forgetfulness is such a book; it springs to mind when I respond to students' questions and is often open on my office desk. Forgetfulness begins with a discussion of time periods before a modern age of forgetting. The first chapter, 'Cultures of Memory', considers various ancient civilizations and their perspectives on time in contrast with that of modern Western civilization. In the second chapter, O'Gorman discusses the causality of modern forgetting in relation to the advent of Christianity. He goes on to posit that forgetting is a result of modernity's adoration of consumption, which he discusses at length in the following chapter on consumerism ('Contemporary Cultures of Amnesia'). Chapter four comprises an exploration of modern narratives and their implications in the loss of history. In the fifth chapter, 'Learning Pasts', O'Gorman argues the complicity of academia in encouraging such social tendencies and in promoting its application to literary studies. In the sixth and final chapter, 'The Problems of Forgetting National and Local Histories', the cultural evidence of resistance to forgetfulness are traced through gatherings of walkers and explorers who seek to connect with a near-ancient past and redeem the decadence of modernity.

O'Gorman identifies New Age trends in the twentieth-century Western world as examples of these attempts to reconnect with cultural memory. Ironically, to a twenty-first century perspective New Age fascinations may themselves seem a dated decadence, as the majority of the middle class is too mired in a frenetic pursuit of economic survival to participate in such pastimes. Yet O'Gorman points out that remnants remain, and the fact that they arise in societies which particularly foster individualism reveals that foundational human needs are not being met. Among these needs is the necessity of community, which 
affirms a duty to support one another in daily battles to exist humanely. These battles are a common calling, transcending time and place in ways that are traceable if we search for them.

Forgetfulness is full of insightful points and crucial discussions of the relationship between lost cultural memory and the modern habit of forgetting. Of particular note, chapter five, 'Learning Pasts', is very much a section about caution when teaching and writing in a culture of amnesia-something that all of academia, not just literary studies, should take under advisement. However, there are some areas in the book that could be better articulated, such as O'Gorman's discourse in chapter three ('Contemporary Cultures of Amnesia') on our 'hyperventilating appetite for change'. 'Specifically, in a consumerism-driven society, labelling a product as 'new and improved' is often a ploy for marketing the unwanted (and unneeded) to a passive market audience. What O'Gorman says here is certainly true, but he belabours a point which is apparent to readers who already acknowledge it and could be better argued to those who do not.

A further weakness of the book is O'Gorman's uneven use of source material. He frequently refers to the Oxford English Dictionary. Readers anticipate similar scholarly quality in all his sources, but O'Gorman proceeds to reference trade paperback editions and online texts as well. As a result, it can be puzzling to identify who his target audience really is; it would appear to be a cross-section of academics and the mass market. His frequent discussions of canonical literature suggest an audience of fellow academics; however, I would observe that academic practices necessitate citing the most reliable editions of source texts, as other less rigorously edited versions can easily introduce errors. Readers from outside the university setting may be more willing to indulge such variety of source material and find themselves inspired to investigate authors and books in open-access formats.

O'Gorman's jeremiad against forgetfulness relies on vestiges of the decadence against which he argues. There is a privilege and luxury in choosing to forget or not acknowledge past histories which contrasts sharply with the potential of unelected forgetting from a sudden illness or incapacity that impacts the brain's memory functions. In chapter four, 'Forgetfulness in Contemporary Cultural Narrative', O'Gorman discusses the solemn possibility of this type of forgetfulness, referring to a stroke that he suffered (and is recovering from even as he writes) as a necessary catalyst to create his perspective on forgetfulness and its dangers. To O'Gorman, forgetfulness is inextricably linked to 'the

\footnotetext{
${ }^{1}$ Francis O'Gorman, Forgetfulness: Making the Modern Culture of Amnesia, (New York: Bloomsbury Academic, 2017), p. 82.
} 
threat of losing [him]self, departing from [his] past'. ${ }^{2}$ The prospect of suddenly losing autonomy and selfhood underlies the urgency of O'Gorman's discussion of choosing to forget, as well as reminding the reader that a complete understanding for those of us yet unvisited by medical emergencies could quite possibly lie ahead.

Generally, it is the ability to learn and remember which guides people forward, and the search for connections, however unworldly they might seem, keeps us grounded in our human responsibilities to one another and the planet that we share. What may seem at first glance to be a decadent fascination with an unreachable past may instead be an attempt to find a path humanity can follow together. A contemporary awareness of global realities is emerging from post-Postmodernism, and this globalization becomes a way of resisting ennui and, ultimately, annihilation. Resistance of this sort is well worth exploring and may point to a type of decadence that, rather than relying on a nihilistic outlook, can be redemptive in its celebration of longing for a community of common hope. Although the author might lean on some laurels (well-earned for previous books such as Worrying: A Literary and Cultural History and scholarly contributions to Ruskin studies), Forgetfulness is an insightful exploration of an ephemeral, amnesiac modernity that both warrants careful examination and inspires lingering thought.

Dr. Kay J. Walter, Professor of English and Editor, The English Pub University of Arkansas at Monticello walter@uamont.edu

${ }^{2}$ Ibid., p. 108. 